\title{
Interaction between Ground Squirrels with rattlesnakes in arid
}

\section{Interacción entre ardillas terrestres con serpientes de cascabel en zonas áridas}

\author{
Gabriel P. Andrade-Ponce ${ }^{1}$, Sandra H. Montero-Bagatella ${ }^{1 *}$, Jessica Duran-Antonio ${ }^{1}$, Alberto González-Romero ${ }^{1}$, and Sonia Gallina ${ }^{1}$ \\ ${ }^{1}$ Red de Biología y Conservación de Vertebrados, Instituto de Ecología A. C., Carretera Antigua a Coatepec 351, CP. 91073, El \\ Haya, Xalapa, México. E-mail: gpandradep@unal.edu.co (GPA-P), helena.bagatella@gmail.com (SHM-B), jess.durant@outlook. \\ com (JD-A), alberto.gonzalez@inecol.mx (AG-R), sonia.gallina@inecol.mx (SG). \\ *Corresponding author
}

\begin{abstract}
The predation of ground squirrels by rattlesnakes has influenced the development of specialized anti-predatory strategies by squirrels. This note describes two cases of encounters of squirrels with rattlesnakes in México, captured photographically. The first event is the interaction between an individual of Xerospermophilus spilosoma and one of Crotalus atrox in the Mapimí Biosphere Reserve, Durango, an arid area of the Chihuahuan Desert in northern México. The second event involved two individuals of $X$. perotensis and one of $C$. scutulatus salvini in the Perote Valley, a semi-arid zone of Veracruz. Both squirrel species displayed anti-predation behaviors reported for the genus, as well as the ability to spot snakes and communicate the alert status to other group members; thus, these observations contributes to the knowledge of the natural history of these species.
\end{abstract}

Key words: arid and semi-arid areas; behavior; México; predator-prey; Xerospermophilus.

La depredación de ardillas terrestres por serpientes de cascabel ha influido en el desarrollo de estrategias antidepredatorias especializadas por parte de las ardillas. En esta nota se describen dos casos de encuentros de ardillas con serpientes de cascabel, capturados fotográficamente en México. El primer evento es la interacción entre un individuo de Xerospermophilus spilosoma y uno de Crotalus atrox en la Reserva de la Biósfera de Mapimí, Durango, zona árida del Desierto Chihuahuense al norte del país. El segundo evento lo componen dos individuos de $X$. perotensis y uno de C. scutulatus salvini en el Valle de Perote, zona semiárida de Veracruz. Ambas especies de ardillas presentaron comportamientos antidepredadores reportados para su género, así como la capacidad para identificar a las serpientes y transmitir el estado de alerta a sus congéneres; por lo que estas observaciones contribuyen con el conocimiento de la historia natural de dichas especies.

Palabras clave: comportamiento; depredador-presa; México; Xerospermophilus; zonas árida y semiárida.

(C) 2020 Asociación Mexicana de Mastozoología, www.mastozoologiamexicana.org

Ground squirrels are an important food source for rattlesnakes, representing up to $60 \%$ of their diet (Fitch 1949). As a result, some sciurids have developed specialized antipredator strategies (e.g., resistance to venom, alerting and deterrence behaviors such as tail flagging; Clark et al. 2016). However, the knowledge of these strategies comes from the study of a limited number of species (i.e., Otospermophilus beecheyi; Barbour and Clark 2012; Ayón et al. 2017), while others, such as those of the genus Xerospermophilus, have received less attention in spite of their higher vulnerability from their lesser physical capacity when facing an attack (Hersek and Owings 1993; Clark et al. 2016). In addition, most of their natural history is still unknown, including interactions with predators. Thus, this study aims to describe the anti-predator behaviors of the spotted ground squirrel, locally known as juancito (Xerospermophilus spilosoma) and the endemic Perote ground squirrel, commonly known as chichilote or moto (X. perotensis), during encounters with rattlesnakes in two different locations in México. $X$. perotensis is considered as endangered by the International Union for the Conservation of Nature (IUCN) and as threatened by the Official Mexican Norm NOM 059 (SEMARNAT 2010).
Study Area. The sightings occurred in the Mapimí Biosphere Reserve (MBR) and in the Perote Valley (PV). The $M B R$ is a natural protected area in the Chihuahuan Desert located in the convergence of the states of Durango, Chihuahua, and Coahuila. Its elevation range is 1,100 to 1,400 $\mathrm{m}$ (CONANP 2006). The climate is dry semi-warm, with a mean annual precipitation of $264 \mathrm{~mm}$ and mean annual temperature of $20^{\circ} \mathrm{C}$ (CONANP 2006). The dominant vegetation comprises halophilous grassland and xerophilous shrubland (CONANP 2006). The PV stretches across the border between the states of Veracruz and Puebla. Its elevation ranges between 2,300 and 2,500 m (Gerez 1985). Its climate is semi-arid temperate (García 2001), with a mean annual temperature of $14{ }^{\circ} \mathrm{C}$ and a mean annual precipitation of $500 \mathrm{~mm}$. The vegetation includes pine forests with tascate juniper (Juniperus deppeana), thorny bushes, natural grasslands and induced pastures, hayfields, and halophilous vegetation (Gerez 1985).

Record collection. X. spilosoma was recorded in the MBR on September 10th 2018 through a camera trap (Cuddeback Black Flash ${ }^{\oplus}$, Model 1231; $26^{\circ} 45^{\prime} 37^{\prime \prime} \mathrm{N}, 103^{\circ} 41^{\prime} 03^{\prime \prime}$ W) used for sampling carnivore mammals (Andrade-Ponce 
et al. 2020) and set to capture photographs at 10-second intervals, approximately. The habitat was a shrubland bordering a semi-stabilized dune and dominated by Larrea tridentata and Opuntia imbricata. The record of X. perotensis was a direct observation recorded and digitally photographed on 21th August 2013 near the town of San Anto-

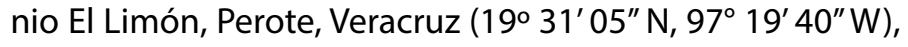
while conducting car trips searching for the species (Montero-Bagatella et al. 2017, 2018).

In the MBR, we recorded the agonistic encounter between $X$. spilosoma and $C$. atrox. The event occurred at $18: 50 \mathrm{~h}$ and lasted 3 minutes; with a total of 14 photographs captured. The first photos show an individual of C. atrox in motion; one minute later, the presence of one specimen of $X$. spilosoma was recorded, which presumably made the snake to change the direction of its displacement (Figure 1). The squirrel intercepted the path of the snake and then adopted a posture that suggests a movement characterized by a rapid tail flagging. In the last frames, the squirrel remained approximately $30 \mathrm{~cm}$ away from the snake until the latter moved out of the camera's field of view.

In the PV, at approximately 14:00 $\mathrm{h}$ we observed the interaction between an individual of $X$. perotensis and an individual of $C$. scutulatus salvini in a short grassland (Bouteloua spp., Aristida divaricata, Bidens anthemoides). The squirrel deployed alerting behaviors while the snake moved across the vegetation. The squirrel adopted a bipedal posture accompanied by cervical movements in search of the snake, with the tail erect, tail flagging, and a repetition of short vocalizations. This behavior was received and replicated by another individual located $30 \mathrm{~cm}$ away. The squirrels kept a distance of 30 to $40 \mathrm{~cm}$ from the snake while moving quickly, in a parallel direction to it (Figure 2; Appendix 1). On several occasions, the squirrels crossed their paths, they stopped, adopted a bipedal position and vocalized. The vocalizations continued for some additional 1 to 2 minutes, despite the snake already being far away. The event lasted approximately 4 to 5 minutes.

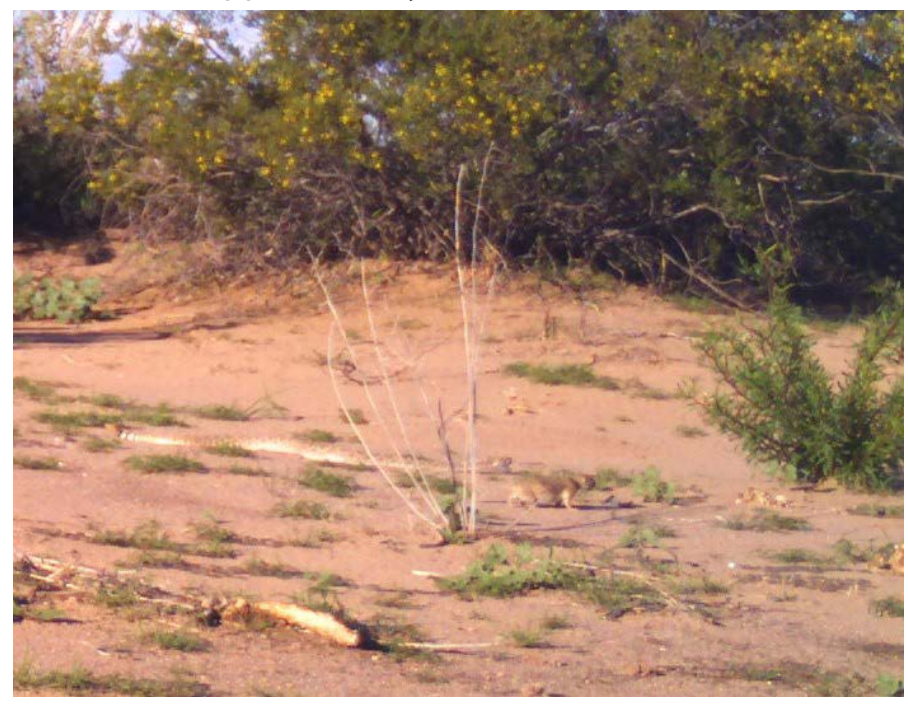

Figure 1. Enlarged photograph of the encounter between the Spotted ground squirrel (Xerospermophilus spilosoma) and a Western diamond-backed rattlesnake (Crotalus atrox) in the Mapimí Biosphere Reserve, México.

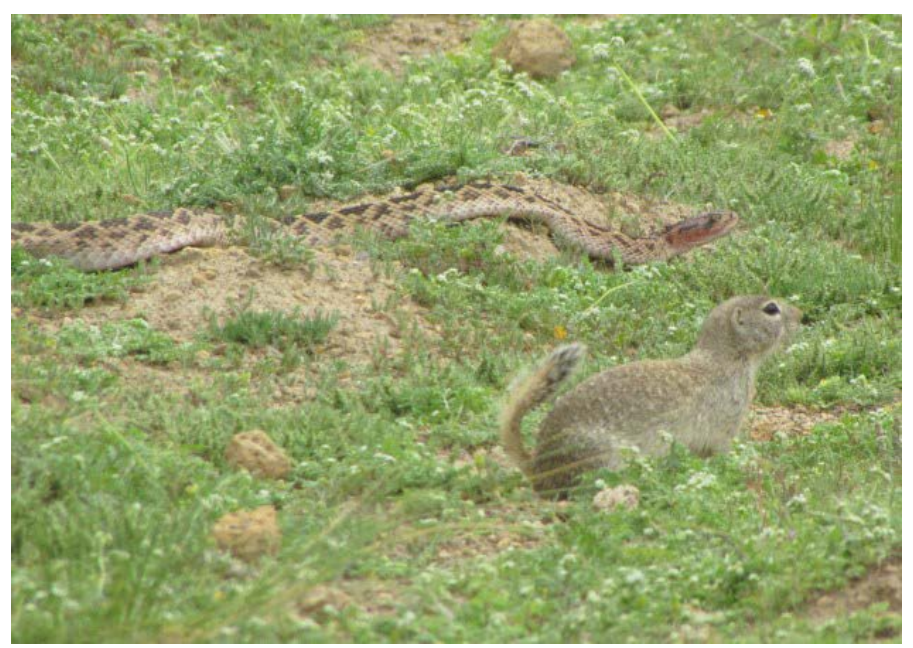

Figure 2. Photographic records of the encounter between a Perote ground squirrel (Xerospermophilus perotensis) and a Perote grassland rattlesnake (Crotalus scutulatus salvini) at Perote Valley, México.

The squirrels exhibited anti-predator behaviors as reported for species of the same genus, including tail flagging, inspection of the predator, and vocalizations to alert other squirrels (Clark et al. 2016). In the case of X. perotensis, the vocalizations and alertness status were maintained after the withdrawal of the predator, which is likely to increase the chances of survival in future attacks (Putman and Clark 2014). Nevertheless, this was not evidenced for $X$. spilosoma due to methodological limitations of cameratraps. Ictidomys mexicanus, a species of similar size to those studied, is resistant to rattlesnake venom and can even get to counterattack the snake (Martinez et al. 1999). However, the records obtained are not conclusive as to the presence of these traits in the studied species. Nonetheless, the observations reported here suggest the ability of both species to detect the presence of snakes and producing communication alerts to other nearby squirrels. The above provides approximations about the natural history and evolution of interacting species, as characteristics such as size, physiology, habitat, and coevolution with the predator influence anti-predator behaviors; which may differ in species of close lineages (Clark et al. 2016). Therefore, further research efforts are needed to characterize the anti-predator strategies of species of the genus Xerospermophilus.

\section{Acknowledgements}

The study conducted at the MBR was funded by the Rufford Foundation (Project No. 24127). We are grateful to R. Cervantes-Huerta for support in video editing, and to $F$. Herrera, A. Rojas and R. González-Trápaga for their invaluable support in the field. M. E. Sánchez-Salazar translated the manuscript from the original in Spanish.

\section{Literature cited}

Andrade-Ponce, G. P., S. Gallina, B. Gómez-Valencia, and A. LiraNoriegA. 2020. Coexistencia de Vulpes macrotis y Canis latrans (Carnivora: Canidae) en la Reserva de la Biosfera de Mapimí, México. Revista Mexicana de Biodiversidad 91:e912973. 
Ayón, R. E., B. J. Putman, and R. W. Clark. 2017. Recent encounters with rattlesnakes enhance ground squirrel responsiveness to predator cues. Behavioral Ecology and Sociobiology 71:149.

Barbour, M. A., and R. W. CLARK. 2012. Ground squirrel tail-flag displays alter both predatory strike and ambush site selection behaviors of rattlesnakes. Proceedings of the Royal Society B: Biological Sciences 279:3827-3833.

Clark, R. W., S. W. Dorr, M. D. Whitford, G. A. Freymiller, and S. R. Hein. 2016. Comparison of anti-snake displays in the sympatric desert rodents Xerospermophilus tereticaudus (roundtailed ground squirrels) and Dipodomys deserti (desert kangaroo rats). Journal of Mammalogy 97:1709-1717.

COnanp (Comisión Nacional de Áreas Naturales Protegidas). 2006. Programa de Conservación y Manejo Reserva de La Biosfera Mapimí. CONANP, Ciudad de México, México.

Fiтch, H. S. 1949. Study of snake populations in central California. The American Midland Naturalist 41:513-579.

García, E. 2001. Climas (clasificación de Koppen, modificado por García). Escala 1:1000000. UNAM, Ciudad de México, México.

Gerez, P. 1985. Uso del suelo durante cuatrocientos años y cambio fisionómico en la zona semiárida Poblano-Veracruzana, México. Biótica 10:123-144.

Hersek, M. J., and D. H. Owings. 1993. Tail flagging by adult California ground squirrels: a tonic signal that serves different functions for males and females. Animal Behaviour 46:129-138.

Martinez, R., J. Pérez, E. Sánchez, and R. Campos. 1999. The antihemorrhagic factor of the Mexican ground squirrel (Spermophilus mexicanus). Toxicon 37:949-954.

Montero-Bagatella, S. H., A. González-Romero, S. Gallina, and G. SÁnchez-RojAs. 2017. Relación entre las características de la vegetación y las densidades de la ardilla de Perote. Revista Mexicana de Biodiversidad 88:691-700.

Montero-Bagatella, S. H., A. González-Romero, G. Sánchez-RoJAS, and S. Galuina. 2018. Annual cycle of the Mexican ground squirrel (Xerospermophilus perotensis). Therya 9:113-120.

Putman, B. J., and R. W. Clark. 2014. The fear of unseen predators: ground squirrel tail flagging in the absence of snakes signals vigilance. Behavioral Ecology 26:185-193.

SEMARNAT (Secretaría de Medio Ambiente y Recursos Naturales). 2010. Norma Oficial Mexicana NOM-059-SEMARNAT-2010, Protección ambiental, especies de flora y fauna silvestres de México, categorías de riesgo y especificaciones para su inclusión, exclusión o cambio, lista de especies en riesgo. Diario Oficial de la Federación de México. Accesed December 30, 2010.

Associated editor: Cristian Kraker

Submitted: December 18, 2019; Reviewed: February 18, 2020.

Accepted: March 11, 2020; Published on line: April 2, 2020.

\section{Appendix 1}

Video of the encounter between Xerospermophilus perotensis and Crotalus scutulatus salvani at Perote Valley, México.

https://drive.google.com/file/d/1LUWGZ61Q0 BCuFLoeJ6v8Rd $15 \mathrm{kLCe} /$ view 